Meta

Journal des traducteurs

Translators' Journal

\title{
Semantic Models for the Translation of Greek Institutional Terms in the Field of Education
}

\section{Eleni Kassapi}

Volume 51, numéro 1, mars 2006

URI : https://id.erudit.org/iderudit/013000ar

DOI : https://doi.org/10.7202/013000ar

Aller au sommaire du numéro

Éditeur(s)

Les Presses de l'Université de Montréal

ISSN

0026-0452 (imprimé)

1492-1421 (numérique)

Découvrir la revue

Citer cet article

Kassapi, E. (2006). Semantic Models for the Translation of Greek Institutional Terms in the Field of Education. Meta, 51(1), 160-165.

https://doi.org/10.7202/013000ar
Résumé de l'article

Cet article prend en compte la problématique des traducteurs du grec vers l'italien et de l'espagnol vers le grec par rapport à l'insuffisance de la terminologie universitaire. Cette situation pose des difficultés dans les équivalences entre les langues. 


\title{
Semantic Models for the Translation of Greek Institutional Terms in the Field of Education
}

\author{
ELENI KASSAPI \\ Aristotle University of Thessaloniki, Thessaloniki, Greece \\ kassapi@itl.auth.gr
}

\begin{abstract}
RÉSUMÉ
Cet article prend en compte la problématique des traducteurs du grec vers l'italien et de l'espagnol vers le grec par rapport à l'insuffisance de la terminologie universitaire. Cette situation pose des difficultés dans les équivalences entre les langues.
\end{abstract}

\begin{abstract}
This article takes under consideration a notorious problem area for Greek $<>$ Italian and Spanish $<>$ Greek translators, caused by the gap of standardized international academic terminology, a situation that creates incongruity: 1) between the Italian and the Greek terms and 2) between the Spanish and the Greek terms, as Greek institutional academic terms have potential Italian and Spanish equivalents with a similar core but different edges.
\end{abstract}

\section{MOTS-CLÉS/KEYWORDS}

quantitative categories, professional categories, Greek academic information, academic terminology

\section{Introduction}

In translation, in the field of education, we meet the notorious-problem-area (P. Kussmaul 1994: 1-13) of institutional terms. The Greek terms ptixio, eparkia, metaptixiako diploma, and didaktoriko diploma have similar core but different edges in relation to their potential equivalents in Spanish and to some extent in Italian. ${ }^{1}$ In the category of academic titles of studies, around the fuzzy edges, ${ }^{2}$ some features of the above mentioned terms are not qualitative but quantitative. ${ }^{3}$ In an academic context, meanings around the fuzzy edges of such categories have to be rendered by Greek translations. ${ }^{4}$

In my discussion, I examine the relevance of two semantic models for the comprehension of the translation process of: i) three translations of the Greek academic terms lektoras, monimos lektoras, epikuros ka8ijitis, monimos epikuros ka8ijitis, anaplirotis ka8ijitis, ka8ijitis, ii) some translation units such as pedagojiki eparkia, metaptixiako diploma, activated in a notorious number of official translated documents on the occasion of the election of a Spanish teacher in a Greek Department. The two semantic models are: 
a) prototype semantics: In Kussmaul, prototype semantics "is based on the idea that when comprehending and producing linguistic utterances we think in holistic notions which are determined by our experiences and they have a hard core and fuzzy edges." The Greek academic institutional terms for teaching and research stuff, such as lektoras, monimos lektoras, epikuros ka8ijitis, monimos epikuros ka8ijitis, anaplirotis ka8ijitis, ka8ijitis have a common feature such as "ability to teach and do research." This common core does not answer questions such as "what about epistimoniki sinergates ${ }^{5}$ or 407?."6 Epistimoniki sinergates or 407 are not prototypical members of the category teaching and research stuff but belong to the fuzzy edge of the category "academic teaching stuff" and are often researchers. In the group of terms lektoras, monimos lektoras, epikuros ka8ijitis, monimos epikuros ka8ijitis, anaplirotis ka8ijitis and ka8ijitis all represent members of the category teaching and research stuff. But a lektoras cannot become a tutor in the space of postgraduate studies if he or she is not a monimos lektoras; a lektoras and epikuros do indeed teach but do not have permanent positions unless they are monimi; and only an anaplirotis and ka8ijitis are able to assume administrative roles in their departments, faculties and universities. How do we interpret "teaching staff and research staff"? That "teaching and reserch" staff is a quantitative category becomes clear from the fact that the required qualifications for the memberhip in such professional categories vary in different countries and are regulated by law. Researcher too is a quantitative category regulated by law (when can a person be identified as researcher?). The terms lektoras, ${ }^{7}$ monimos lektoras, ${ }^{8}$ epikuros ka8ijitis, ${ }^{9}$ monimos epikuros ka8ijitis, ${ }^{10}$ anaplirotis ka8ijitis ${ }^{11}$ and ka8ijitis ${ }^{12}$ are where the fuzzy edges of meanings become visible and where culture influences meaning.

b) scenes-and-frames semantics: ${ }^{13}$ In Kussmaul "this psycholinguistic model starts from the basic idea that in process of comprehension linguistic forms activate meaning stored in the listener's/reader's memory. The scenes and frame model help to describe the interplay between potential experiential meaning of words or other linguistic forms and the context or situation in which they are used and which modifies or enlarges or changes their potential meaning. When translating we find that words are used in an unexpected, new or unknown sense."

\section{Problem identification}

The focus of my discussion is the problem of translating and sometimes adapting Greek academic information to the Italian target culture and Spanish institutional academic terms to the Greek target culture ${ }^{14}$ as international institutional academic terms: Again in Kussmaul these terms a) often overlap only in the core but not at the edges, b) there are word meanings with clear-cut edges, c) there is no standardized international academic terminology aiming at precision, a situation that causes incongruence due to non-equivalences.

\section{Problem description}

In order to define rational behaviour choices (W. Wilss 1994: 131-150) in bilingual Greek $<>$ Italian or Spanish $<>$ Greek translation of academic terms we must confirm whether a translation satisfies the following four basic requirements: a) verifiability (pragmatic dimension), b) plausability (thematic dimension), c) situational adequacy (functional dimension), d) value-orientedness (target-language/text readership). 


\section{Information collection}

The decision-making behaviour of the translators is demonstrated by the textual facts of any resultant translation. In Wilss, decision-making behaviour in the translation and, in our case, in the translation of academic institutional terms is described in terms of an interaction between the following factors: "a) activation of linguistic, referential, sociocultural and situational knowledge-based systems, b) specification of text-type-problem space."

The above factors $3 \mathrm{a}$ and $3 \mathrm{~b}$ enable the translator of academic institutional terms to build up an internal problem representation (W. Wilss 1994: 131-150) which will influence her/his performance, taking account of alternative choices which are an important element in our specific educational and institutional setting.

\section{Deliberation of how to proceed}

The translation situations under discussion contain an element of risk as they require some form of non-trivial choice. In Wilss, in the cases under discussion, the translator "has to objectify (W.Wilss 1994: 131-150) the translation problem in view of the fact that she/he must take into consideration cross-cultural differences in assessing the given decision-making situation, so that different decision-making strategies may be employed in the same translation situation," i.e., Table 1. This Table describes decision-making processes and problem-solving operations making clear factors and criteria in the course of the particular translation action under discussion. Again according to Wilss, "in achieving the situationally synchronization of source and target texts, we have to define the linguistic, extra-linguistic and sociocultural resources of the translator when she/he was trying to perform intertextual balancing acts aiming to conform the intention of the source-text author and the expectations of the target-language reader." In the case of my discussion the translator relies on the cooperation of the source-text author [the SL-author is identical with the TL-author or they communicate in the same professional context]

\section{Examples of existing translational choices}

In order to solve the specific translation problems under discussion, the translators have activated two types of knowledge (W. Wilss 1994: 131-150): a) Declarative knowledge (= stored-up knowledge and expertise), b) Processual knowledge (= strategic knowledge). The types of knowledge activated by the translators are demonstrated by the textual facts of the translation results in discussion. 


\section{5a) Table 1}

A=The Study Guide 2000-2001, Department of Italian Studies, AUTH, pp. 9, 74/ B= The Study Guide 2001 - 2002, Department of Italian Studies, AUTH, pp. 11, 88/ C= The Study Guide 2002 2003, Department of Italian Studies, AUTH, pp. 9-10, 98.

\begin{tabular}{|l|l|l|l|}
\hline & A & B & C \\
\hline $\begin{array}{l}\text { Greek academic } \\
\text { termterms }\end{array}$ & $\begin{array}{l}\text { The Italian } \\
\text { translation } \\
\text { [as derived activity }\end{array}$ & $\begin{array}{l}\text { The Italian } \\
\text { transtranslation }\end{array}$ & $\begin{array}{l}\text { The Italian } \\
\text { translation } \\
\star * \star *\end{array}$ \\
\hline Ka8ijitis & $\begin{array}{l}\text { Prof. di ruolo**-I } \\
\text { fascifascia\# }\end{array}$ & $\begin{array}{l}\text { Professore } \\
\text { Ordinario }\end{array}$ & $\begin{array}{l}\text { Professore ordinario } \\
\text { 1a fasciFascia\#\#\# }\end{array}$ \\
\hline Anaplirotis ka8ijitis & $\begin{array}{l}\text { Prof. di ruolo- } \\
\text { II fascia }\end{array}$ & $\begin{array}{l}\text { Professore } \\
\text { Associato }\end{array}$ & $\begin{array}{l}\text { Professore ordinario } \\
\text { 2a fasciFascia }\end{array}$ \\
\hline $\begin{array}{l}\text { Monimos Epikuros } \\
\text { Ka8ijitis }\end{array}$ & Nobody & $\begin{array}{l}\text { Professore associato } \\
\text { 1a fasciFascia }\end{array}$ \\
\hline Epikuros ka8ijitis & $\begin{array}{l}\text { Prof. di ruolo- } \\
\text { III fascia }\end{array}$ & $\begin{array}{l}\text { Professore } \\
\text { Ricercatore\#\# }\end{array}$ & Nobody \\
\hline Monimos lektoras & $\begin{array}{l}\text { Prof. di ruolo- } \\
\text { IV fascia }\end{array}$ & $\begin{array}{l}\text { Professore } \\
\text { Lektoras }\end{array}$ & $\begin{array}{l}\text { Professore associato } \\
\text { 2a fasciFascia }\end{array}$ \\
\hline Lektoras epi 8itia $^{*}$ & $\begin{array}{l}\text { Prof. di ruolo- } \\
\text { IV fascia }\end{array}$ & $\begin{array}{l}\text { Professore } \\
\text { Lektoras }\end{array}$ & \\
\hline
\end{tabular}

* There is no equivalence in Italian because the potential equivalent roles are only three ${ }^{15}$ : Professore ordinario, Professore associato, Ricercatore universitario.

** Di ruolo as polysemic term even means in permanent position. In the Greek academic context this does not follow the pragmatic requirement of such a translation.

$* * *$ Direct loan from Greek to Italian, adopted first by me in $2000 .{ }^{16}$

**** The translation results in column C not reproducing the embodied metaphor of order (Lakoff 1996: 81-84/ 1990: xiv, ) and hierarchy, in term of membership gradience (Lakoff 1990: 13), in Greek academic context.

\# Gazzetta Ufficiale della Repubblica Italiana, serie generale, n. 138, p. 44.

\# Ricercatore universitario, (Universita' degli studi di Trento, Legge Istitutiva e Statuto, p. 31).

\#\#\# improper use of the term fascia because here the result is a non-verifiable scale of gradience.

5b) I return to the terms pedagojiki eparkia (Aptitud Pedagogica), "metaptixiako" diploma (Suficienzia Investigadora), activated in a notorious number of official translated documents on the occasion of the election of a Spanish teacher in a Greek Department. Eparkia in the Greek academic context has a negative value and Suficienzia Investigadora is not a title of the MA type. These two translations can produce underestimation or overestimation in the context of an academic election [teaching staff].

\section{Evaluation of translation results}

For this request we must make the distinction between macro-textual strategies and micro-textual problems in the cases $5 \mathrm{a}$ and $5 \mathrm{~b}$ described here.

Case 5a: The sender is a Greek academic institution, the addressees form a homogeneous group of Italian academics. The wording of the translations is not targetoriented The information as presented is distorted Parallel texts must be used in the 
future in order to obtain models for direct imitation (M. Snell-Hornby 1988: 116128).

Micro-textual (K.Kaindl 1999: 263-288) problems including episodic phenomena such as a) adiectio of the terms "di ruolo" for "prof. di I fascia" [Column A], and "professore" for "ricercatore universitario" [Column B], b) deletion of the translation of terms such as "monimos lektoras" and "monimos epikuros," c) non-successful substitution and for this reason transmutation of the membership gradience scale [Column C] give a translation result which does not satisfy the basic requirements of: a) verifiability, b) plausability, c) situational adequacy, d) value-orientedness.

Case 5b: Micro-textual problems phenomena such as a) repetition (pedagojiki eparkia for Aptitud Pedagogica) and b) non-successful subsitution ("metaptixiako" diploma for Suficienzia Investigadora) produce translations which do not satisfy the basic requirements of: a) verifiability and b) situational adequacy.

The explanatory value of the two semantic models for the translation of Greek institutional terms in the field of education can be used in translation teaching. By making use of the two models in combination with objective translation assessment, we can make our students aware of the comprehension and production processes involved in translation.

\section{NOTES}

1. The protypical concepts of the Spanish terms, in discussion, are described in the following way by the Ley de Reforma Universitaria 1983, Ley Organica del Systema Educativo 1985 and Annexe I about the "General Official Announcement of "Foreign Office Scholarship Awards" of the "SCHOLARSHIP AWARDS FOR STUDIES IN SPAIN UNDERTAKEN BY FOREIGN NATIONALS AND STUDIES UNDERTAKEN BY SPANISH NATIONALS ABROAD": i) Licenciado="the courses of studies leading to Licenciado consist of first cycle and second cycle studies (long term studies) but a degree is awarded only when the studies of both cycles have been completed successfully," ii) Suficienzia Investigadora=The first substage for the third stage of university studies is open to holders of a Licenciado and leads to undertake a Doctoral thesis, iii) Doctor's Degree $=$ is awarded after a total (see ii+iii of this footnote) of four years' study and research, and after the submission and defence of a thesis, iv) Aptitud Pedagogica= In order to be able to teach, holders of Licenciado must also hold the Certificado de Aptitud Pedagogica following a two semesters' course./ The prototypical concept of the Italian term dottore (dr) is the following "chi e' fornito dal diploma di laurea di una focolta" universitaria" (Lo Zingarelli 1995, Vocabolario della Lingua Italiana) in Greek "dr"in the academic contex has the meaning of the existence of a Ph.D. As translators we have to decide which degree of precision will be necessary in the Greek translation of the above terms.

2. Fuzzy edges: By Kussmaul "Linguistic categories have a hard core and fuzzy edges. The metaphor suggests that there is a central meaning (the core) and a peripheral meaning (fuzzy edges).

3. Thus implying that there are no clear-cut edges because around the fuzzy edges the culture within time influences our concepts. This is supposed by the report of the Spanish Ministry of Instruction: "The Bologna Declaration appeared when Spanish universities were performing their second national curricula reform. This fact together with a variety of (bad) translations into Spanish produced some confusion and, even worse, it was used as an argument to come back to traditional former schemes... The new National University Law (Ley Organica de Universidades) recently approved in the Parliament, includes articles (titulo 13o) giving the government the right to and the mission of developing the regulations to implement, within the Spanish system, the European credits, the Diploma Supplement, the BA/MA structure, the quality assessment, etc. The Minister announced that is going to be completed in two, or a maximum of three years" (Luciano Galan).

4. This means, by the facts and by Kussmaul, that when it will come the moment to standarize internation academic terminology there can be problems.

5. Academic teaching role determined by law.

6. Academic teaching contractual role determined by law. 
7. Lektoras: This role is open to holders of $\mathrm{PhD}$ with two years' professional experience and two collective or individual publications. The process of the election is determined by the law.

8. Monimos lektoras: This role is open to holders of $\mathrm{PhD}$ with seven years' teaching experience at the university, two collective or individual publications. The process of the election is determined by the law.

9. Epikuros ka8ijitis: This role is open to holders of $\mathrm{PhD}$ with a) two years' teaching experience at the university after being awarded the $\mathrm{PhD}, \mathrm{b}$ ) after three years' of teaching experience in the degree of lektoras, and a number of collective or individual publications. The process of the election is determined by the law. Does not participate at the process of the election of monimos epikuros.

10. Monimos epikuros ka8ijitis: This role is open to holders of $\mathrm{PhD}$ with a) three years' teaching experience in the degree of monimos lektoras and a number of collective or individual publications, b) three years' teaching experience in the degree of epikuros ka8ijitis and a number of collective or individual publications. The process of the election is determined by the law.

11. Anaplirotis ka8ijitis: This role is open to holders of $\mathrm{PhD}$ with four years' teaching experience at the university after being awarded the $\mathrm{PhD}$, a number of individual and collective publications, a clear contribution to the scientific research. The process of the election is determined by the law.

12. Ka8ijitis: This role is open to holders of $\mathrm{PhD}$ with six years' teaching experience at the university after being awarded the $\mathrm{PhD}$, a number of individual publications, a clear contribution to the scientific research, international recognition. The process of the election is determined by the law.

13. Paul Kussmaul (1994) Target 6:1, 1-13, frame = linguistic form/ scene $=$ is the meaning of the linguistic forms, frames have to be filled by the readers or listeners with something almost visible, at least experiential, scenes are prototypical but their meaning is not static and permanent and is influenced or created by the communicative situation.

14. Greek institutional academic terms have potential Italian and Spanish equivalents with a similar core but different edges, when translating these terms, we must decide what to preserve:i) the core, ii) the core and the edges, iii) or the edges only.

15. Universita' degli studi di Trento, Legge Istitutiva e Statuto, p. 31.

16. ISBN 960-12-1120-9 (p.12). This term is adopted by the Commision of The Study Guide (Column $\mathrm{B}$, Table 1) to avoid confusion with the meaning of the term «Lettore» as this in the Italian academic context reppresents a not equivalent role.

\section{REFERENCES}

De Mauro, T. (1994): Capire le parole, Roma, Laterza.

Gorlee, D. (1994): Semiotics and the Problem of Translation with Special References to the Semiotics of Ch. S. Pierce, Amsterdam, Rodopi.

KaINDL, Kl. (1999): Comics under Translation, Target 11-2, p. 263-288.

Kussmaul, P. (1994): Semantic Models and Translating, Target 6-1, p. 1-13.

LAkoff, G. (1996): Moral Politics, The University of Chicago Press.

Lakoff, G. (1994): Women, Fire and Dangerous Things, The University of Chicago Press.

Snell-Hornby, M. (1988): Translation Studies. An Integrated Approach, Benjamins.

Wilss, W. (1994): Decision-Making in Translation, Target 6-2, p. 131-150. 